\title{
CONTENTS OF THORIUM, URANIUM AND POTASSIUM OF THE UPPER PERMIAN MUDSTONES AND SANDSTONES IN THE SOUTHERN KITAKAMI MOUNTAINS, JAPAN
}

\author{
Hiroshi Kanaya and Masato Katada
}

Geological Survey of Japan, Kareasaki

\section{INTRODUGTION}

The upper Permian sediments distributed in the southern Kitakami Mountains consist of two facies; "mudstone facies" composed predominantly of mudstone and

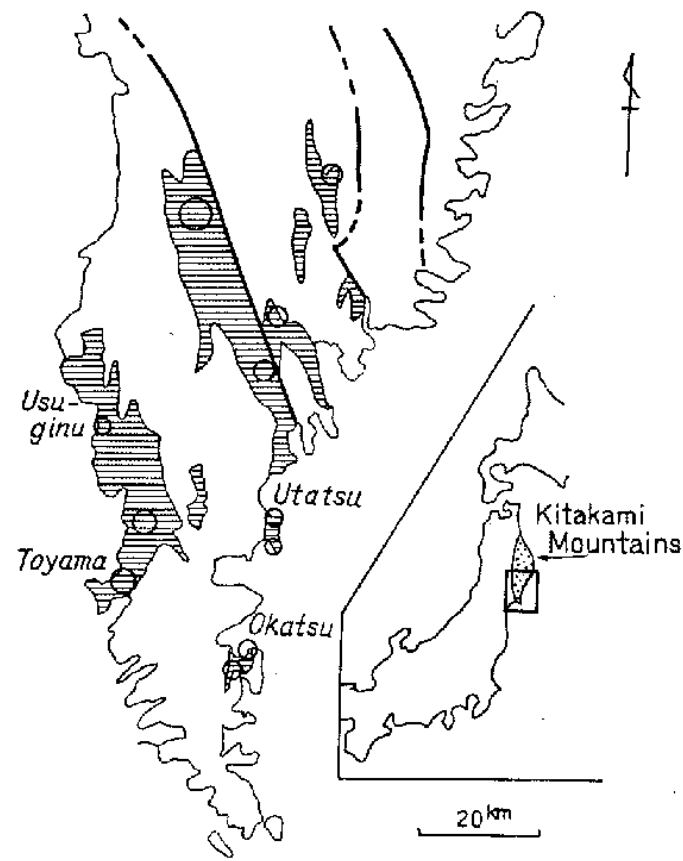

Fig. 1. Distribution of the mudstone and congl. omerate facies.

Shaded area: The mudstone and conglomerate facies.

Circle: Sampling localities. "conglomerate facies" composed mainly of conglomerate (Fig. 1). The former is commonly called the Toyoma slate and the latter the Usuginu conglomerate. The mudstone is characteristically black and contains few fossils and hardly shows sedimentary structures such as grading and lamination, etc. From these features, Minato (1950) presumed that the mudstone facies named the "Toyoma facies" was one of sapropelic sediments accumulated in an inland sea. Kondo (1966) reported considerably high contents of U, 10 and 11 ppm, from this mudstone.

Having given eight chemical analyses of the mudstone, Kambe et al. (1969) reported that their organic carbon was all less than 1 in weight percentage. Such concentration is too low to name the mudstone "carbonaceous or black shale" (Swanson, 1961). Ishihara et al. (1969) found that the $U$ content (average, $2.2 \mathrm{ppm}$ ) was as low as average contents of common pelitic rocks. The last mentioned two facts are rather contradictory to the conclusions of the first two papers.

The purpose of this paper is to describe new results obtained from detailed measure- 
ments of the content of $\mathrm{U}$ as well as those of Th and $\mathrm{K}_{\mathrm{g}} \mathrm{O}$ by the $\gamma$-spectrometric method on the samples extensively collected from the mudstone and conglomerate facies. These data are the first results of a systematic investigation on radioactive elements in ordinary sedimentary rocks in Japan, and they will be of potential use for studies of the sedimentary processes of the mudstone facies.

Contents of the elements, and localities and rock types of all the measured samples are given in another paper (Kanaya et al., 1975).

\section{GEOLOGY}

The mudstone facies has been interpreted to be a miogeosynclinal one or its allied sediments of middle to latest Permian age. The facies can be divided into two arbitrary subfacies, "silty" and "clayey" ones, on the basis of the stratigraphical and lithological evidence (Fig. 2).

The silty subfacies consists chiefly of siltstone and silty claystone, and the clayey

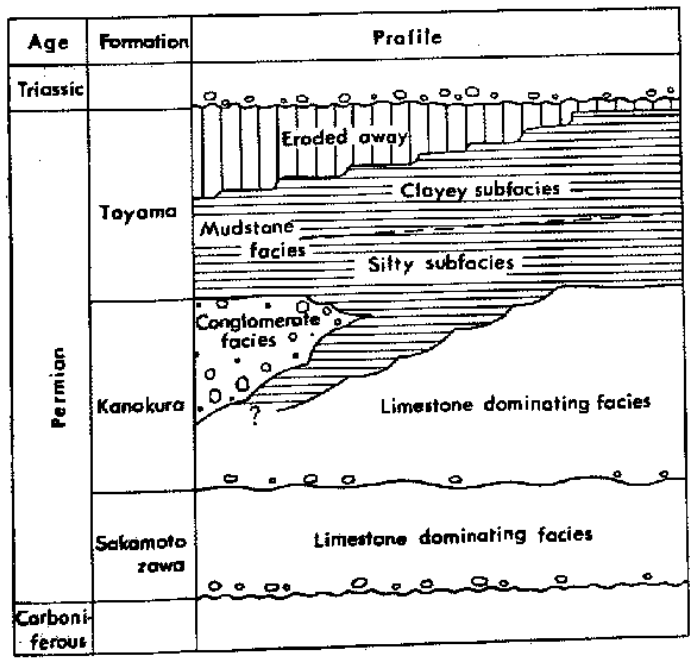

Fig. 2. Idealized profile of the Permian formations in the southern Kitakami Mountains. subfacies of claystone and silty claystone. The two subfacies are intercalated with a few beds of sandstone and such calcareous rocks as impure limestone and calcareous mudstone.

The Toyoma Formation includes the clayey subfacies in the upper and upper part of the silty subfacies in the lower (Fig. 2). From the paleontological point of view, the Toyoma Formation is classified into three fossil zones, $\mathrm{Tl}, \mathrm{Tm}$ and Tu (Working Group on the Permian-Triassic Systems, 1975). The boundary between the silty and clayey subfacies exists in the middle or upper part of the $\mathrm{Tl}$ zone which corresponds to so called Bellerophon zone. The uppermost beds, the Tu zone, crop out only in the Utatsu area and consist mainly of silty claystone, accompanied by sandstone. In this area, the total thickness of the mudstone facies is nearly $1,700 \mathrm{~m}$, but it is less than $1,000 \mathrm{~m}$ in the other areas.

The mudstone was wholly converted into typical slate owing to the Oshima orogenic movement of middle Cretaceous age. Main constitutents of the mudstone are detrital plagioclase, quartz and altered biotite in the order of abundance, accompanied by authigenic chlorite, sericite, calcite, graphite and iron minerals. The sandstone is calcareous to some extent (calcite, less than $30 \%$ ), being composed of plagioclase, quartz and volcanic fragments, etc. The calcareous rocks named here include impure limestone (calcite, more than $70 \%$ ) and calcareous mudstone (calcite, 20 to $70 \%$ ). Calcite in the sandstone and the calcareous rocks may be mostly of biogenic origin.

As mentioned in the preceding chapter, the mudstone facies is dominant in characteristically black mudstone which occupies more than 85 percent of the silty 
Table 1. Averages of $K_{2} \mathrm{O}, \mathrm{Th}$ and $\mathrm{U}$ contents and $\mathrm{Th} / \mathrm{U}$ ratio in mudstones and sandstones.

\begin{tabular}{|c|c|c|c|c|}
\hline & \multicolumn{3}{|c|}{ Mudstone facies } & \multirow{2}{*}{$\begin{array}{c}\begin{array}{c}\text { Conglomerate } \\
\text { facies }\end{array} \\
\begin{array}{c}\text { Coarse } \\
\text { sandistone }\end{array}\end{array}$} \\
\hline & $\begin{array}{l}\text { Claystono and } \\
\text { silty claystone }\end{array}$ & $\begin{array}{l}\text { Siltstone (with } \\
\text { fine sandstone) }\end{array}$ & $\begin{array}{l}\text { Medium to coarse } \\
\text { sandstone }\end{array}$ & \\
\hline$n$ & 44 & 11 & 15 & 4 \\
\hline $\mathrm{K}_{2} \mathrm{O}(\%)$ & $\begin{array}{c}2.83 \\
(1.27-3.42)\end{array}$ & $\begin{array}{c}1.78 \\
(1.16-2.52)\end{array}$ & $\begin{array}{c}0.94 \\
(0.40-1.52)\end{array}$ & $\begin{array}{c}1.00 \\
(0.69-1.19)\end{array}$ \\
\hline Th (ppm) & $\begin{array}{c}10.4 \\
(1.3-13.4)\end{array}$ & $\begin{array}{c}4.4 \\
(2.3-6.6)\end{array}$ & $\begin{array}{c}2.9 \\
(1.6-5.2)\end{array}$ & $\begin{array}{c}2.3 \\
(1.7-3.2)\end{array}$ \\
\hline$U(p p m)$ & $\begin{array}{l}2.8 \\
(0.8-3.9)\end{array}$ & $\begin{array}{c}3.8 \\
(1.1-2.3)\end{array}$ & $\begin{array}{c}1.0 \\
(0.5-2.0)\end{array}$ & $\begin{array}{c}0.9 \\
(0.8-1.1)\end{array}$ \\
\hline $\mathrm{Th} / \mathrm{U}$ & $\begin{array}{c}3.6 \\
(1.6-5.1)\end{array}$ & $\begin{array}{c}2.4 \\
(1.7-3.1)\end{array}$ & $\begin{array}{c}2.9 \\
(2.3-3.8)\end{array}$ & $\begin{array}{c}2.6 \\
(1.9-2.9)\end{array}$ \\
\hline
\end{tabular}

Numerals in parentheses are ranges of values.

subfacies and more than 95 percent of the clayey subfacies except its uppermost beds distributed in the Utatsu area. It has uniform appearance lacking lamination. Such features suggest that the mudstone, especially that of the clayey subfacies, accumulated slowly and constantly in a tranquil sedimentary basin.

The conglomerate facies interfingers with the silty subfacies partly (Fig. 2). As contrasted with the mudstone facies, the conglomerate facies consists of very coarsegrained sediments, that is, ill-sorted conglomerate rarely interbedded with coarse sandstone. The clasts of the conglomerate and the sandstone predominate in various granitic and volcanic materials. The predominance of granitic materials in the conglomerate facies is in striking contrast to their scarcity in the mudstone facies.

\section{Contents of Thorium, URaniUm AND POTASSIUM}

The contents of $\mathrm{Th}, \mathrm{U}$ and $\mathrm{K}\left(\mathrm{K}_{2} \mathrm{O}\right)$ were determined on ninety-two samples of various rock types including mudstone, sandstone and calcareous rocks which were collected from many localities and different stratigraphic units (Fig. 1). The averages and the ranges of the values of mudstone and sandstone except calcarous rocks are tabulated in Table 1.

The contents of the three elements vary systematically from one rock type to another, and according to the variation the analytical results were classified into four lithologic types, namely, claystone and silty claystone, siltstone including a few fine sandstone, medium to coarse sandstone in the mudstone facies, and coarse sandstone in the conglomerate facies. It shows a general tendency that the contents increase in accordance with the decrease of grain size for all three elements. There are no values higher than $14 \mathrm{ppm}$ for Th and 4 ppm for $\mathrm{U}$ in ordinary mudstone and sandstone.

The contents of calcareous rocks are not 
listed in this table, because their contents vary greatly depending on specimens. The Th contents, for example, range from 2.5 to $7.7 \mathrm{ppm}$ in general, but three exceptionally high values, $12.8,18.8$ and $51.4 \mathrm{ppm}$, are obtained. The $\mathrm{U}$ contents are 1.4 to 3.4 ppm in most of samples, but two specimens give values 5.1 and $10.9 \mathrm{ppm}$.

Both Th and $U$ contents in the mudstone and sandstone are in accordance with already reported values of those in shales and sandstones (Adams et al., 1958; Rogers et al., 1969 a, b; Banno et al., 1969 and Ishihara et al., 1973). The general U content in question, less than $4 \mathrm{ppm}$, is far lower than that in the black shale that was deposited in reduced sea water, which contains usually 5 to $10 \mathrm{ppm}$ or more (Swanson, 1961). It may be indicated that the depositional environment of the ancient "Toyoma Sea" was not strongly reduced condition enough to precipitate $U$ directly from the sea water.

Almost all the composition of $\mathrm{K}_{2} \mathrm{O}$ in mudstone are contained in authigenic sericite in matrix, because other $\mathrm{K}_{2} \mathrm{O}$-bearing minerals such as detrital fresh mica and potassium feldspar are negligible in amount. The $\mathrm{K}_{2} \mathrm{O}$ of sandstone is also contained mostly in sericite. The contents of detrital potassium feldspar in sandstone are less than 0.5 percent in the mudstone facies and less than 2 percent in the conglomerate facies in volume. Accordingly $\mathrm{K}_{2} \mathrm{O}$ content depends on the amount of matrix in a clastic sediment. The finer the grain size of a clastic sediment becomes, the more its matrix generally increases in amount, and hence the finer the grain size of a sediment becomes, the richer it is in $\mathrm{K}_{2} \mathrm{O}$.

The comparison of $\mathrm{K}_{2} \mathrm{O}$ content in the mudstone or sandstone of the silty subfacies with that of the mudstone or sandstone of the same grain size as the above sediments of the clayey subfacies shows that the content of the former is usually smaller than that of the latter. This may be due to sericite/chlorite ratio in the matrix of rocks, the ratio being lower in the silty subfacies than in the clayey subfacies.

The $\mathrm{K}_{2} \mathrm{O}$ content of mudstone, as a whole, is slightly less than the mean contents of $\mathrm{K}_{2} \mathrm{O}$ of pelitic sediments in the world reported by Clarke et al. (1924) and Shaw (1956), 3.24 and 3.45 percent respectively.

\section{Relationships amoNg Thorium, Uranium and Potassium Contents}

As shown in Fig. 3a there is roughly linear and positive correlation between $\mathrm{Th}$ and $\ddot{\mathrm{K}}_{2} \mathrm{O}$ contents in both mudstone and sandstone. It is of much interest that, if the mudstone facies is divided into silty and clayey subfacies, the respective trends for the two subfacies are clearly separated from each another in the diagram, that is, the $T h / K_{z} O$ ratio of the clayey subfacies is higher than that of the silty subfacies. The trend of sandstone of the conglomerate facies is generally the same as that of the silty subfacies. Calcareous rocks do not show any regularity in the diagram (Fig. 3b).

Between $U$ and $K_{2} O$ contents there is a nearly linear relationship in the whole clastic sediments (Fig. 3c). The trend is related to neither the grain size nor the sample localities. In case of calcareous rocks, however, the plotted points are widely scattered (Fig. 3d); its $\mathrm{U} / \mathrm{K}_{2} \mathrm{O}$ ratio being distinctively higher than that of clastic sediments.

$\mathrm{Th} / \mathrm{U}$ ratio is frequently used for discussions on behavior of the two elements in igneous rocks. In the sedimentary rocks 


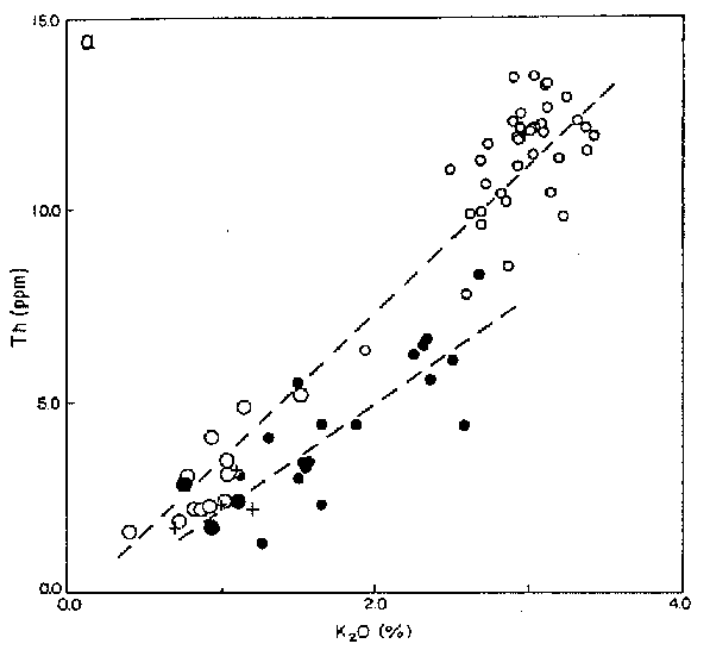

Fig. 3-a,

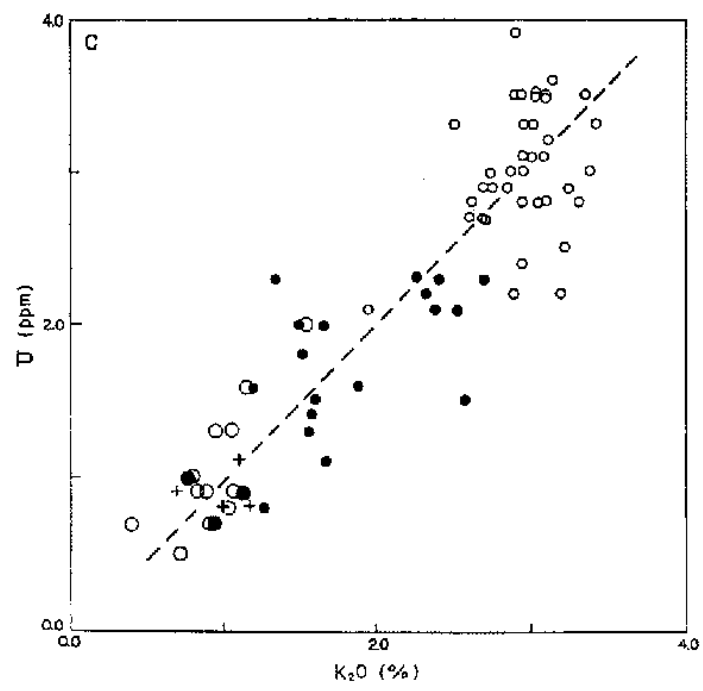

Fig. 3-c,

as well, the ratio is considered as an indicator of weathering condition and the environments of sedimentary processes (Adams et al., 1958). As known well, Th is relatively insoluble under various geologic conditions, while $U$ is easily soluble especially in oxidized circumstances.

Average $\mathrm{Th} / \mathrm{U}$ ratios are $3.6,2.4,2.9$ and 2.6 in claystone and silty claystone, in

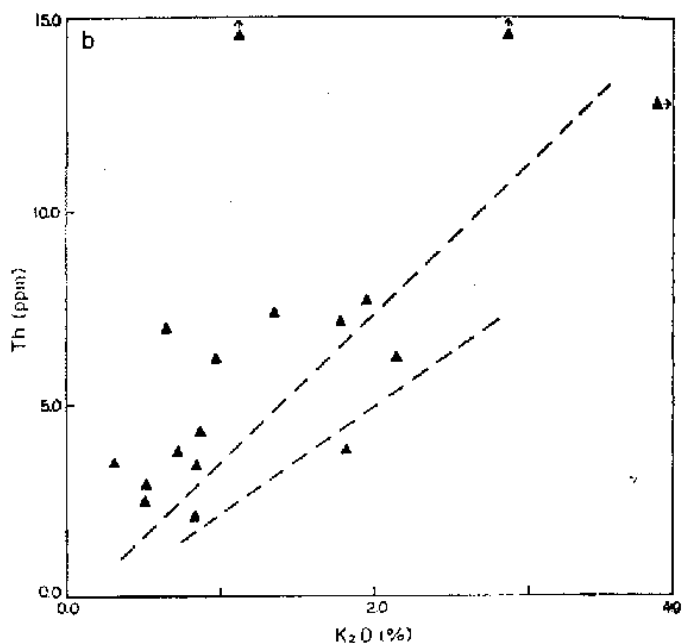

Fig. $3-b$,

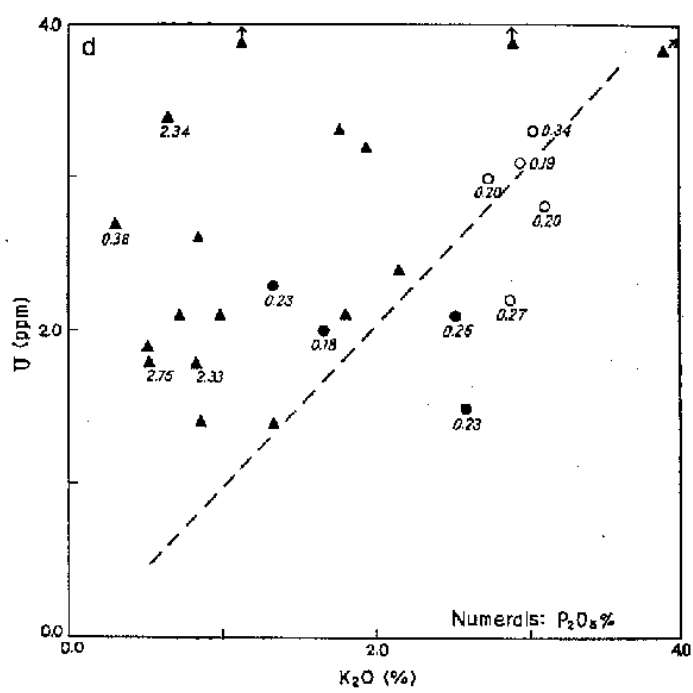

Fig. 3-d,

siltstone, in sandstone of mudstone facies and in sandstone of conglomerate facies, respectively (Table 1). The ratio in claystone and silty claystone is nearly equal to that in ordinary pelitic rocks reported by Adams et al. (1958), Rogers et al. (1969a) and Ishihara et al. (1973). In Fig. 3e, the ratios are presented in detail. The majority of the ratios fall between 2 and 5 , and three 


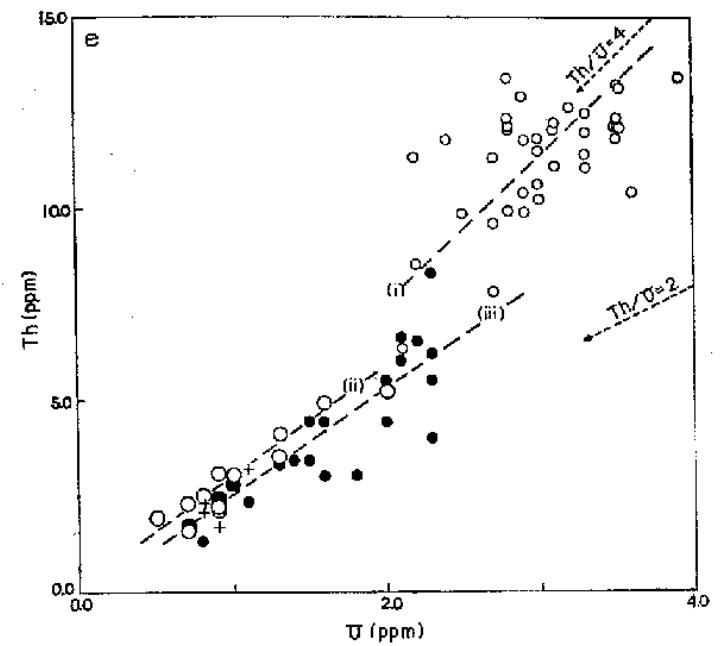

Fig. 3-e,

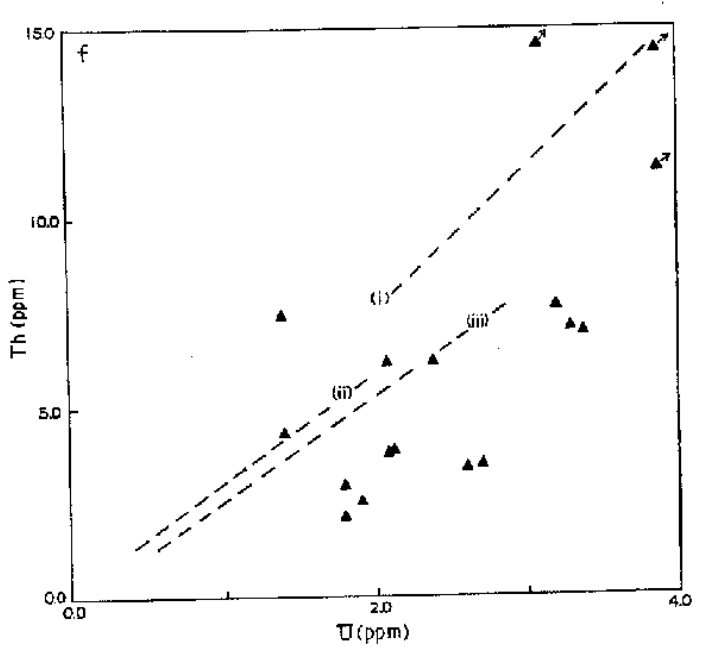

Fig. 3-f,

Fig. 3. Relationships among $\mathrm{Th}, \mathrm{U}$ and $\mathrm{K}_{\mathbf{2}} \mathrm{O}$.

Figs. 3a, $c$ and e: Mudstone (claystone, silty claystone, siltstone and fine sandstone). and sandstone.

Fig. $3 \mathrm{~b}, \mathrm{~d}$ and $\mathrm{f}$ : Calcareous rocks (impure limestone and calcareous mudstone)

Small open circle: Mudstone, the clayey subfacies.

Large open circle: Sandstone, the clayey subfacies.

Small Solid circle: Mudstone, the silty subfacies.

Large Solid circle: Sandstone the silty subfacies.

Cross: Sandstone, the conglomerate fiacies.

Solid triangle: Calcareous rocks, the mudstone facies.

trends are discriminated; i) a trend for claystone and silty claystone of the clayey subfacies, ii) the one for sandstone of the clayey subfacies, and iii) the one for all clastic rocks of the silty subfacies, and sandstone of the conglomerate facies.

The values of calcareous rocks hold a roughly linear trend falling in the same field as those of the clastic sediments, contrary to the author's expectation (Fig. 3f).

\section{Geological INTERPRETATION}

The clastic sediments of the mudstone and conglomerate facies of the upper Permian in the southern Kitakami Mountains have raughly the similar contents of $T h$ and $U$ with ordinary sediments, but their variations are worthy to note.
There are simple correlations among three elements, $T h, U$ and $\mathrm{K}_{2} \mathrm{O}$, in which the relationship between $\mathrm{U}$ and $\mathrm{K}_{2} \mathrm{O}$ contents for the clastic sediments is nearly linear. The grain sizes of the sediments do not affect the values of $\mathrm{U} / \mathrm{K}_{\mathbf{2}} \mathrm{O}$ ratio. Its positive trend that approximately passes the origin of the graph (Fig. 3c) suggests strongly that $\mathrm{U}$ is adsorbed on a $\mathrm{K}_{\mathbf{2}} \mathrm{O}$-bearing mineral, authigenic sericite, in the matrix of the clastic sediments. The linear relationship indicates that the adsorption of $\mathrm{U}$ from sea water was the most important factor to control the amount of $U$ in the rocks. If not, namely, if $U$ had been adsorbed on a clay mineral in the source area, the degree of the adsorption must have been influenced by the weathering condition, and $\mathrm{U}$ content and $\mathrm{U} / \mathrm{K}_{2} \mathrm{O}$ ratio have been 
yariable and not so constant in every formation. Originally illite and sericite have a nature of adsorbing $U$, but $U$ and $\mathrm{K}_{\mathrm{a}} \mathrm{O}$ (or $\mathrm{K}$ ) in sedimentary rocks in natural environment are not always in linear relationship. Accordingly the relationship pointed out in this study is a rare example.

The relationship of Th to $\mathrm{K}_{2} \mathrm{O}$ is similar to that of $\mathrm{U}$ to $\mathrm{K}_{2} \mathrm{O}$. The similar linear relationship was already reported by Pliler et al. (1962a) and Bloxam (1964). From the relationship and their leaching experiments in laboratories, they inferred that $T h$ in pelitic rocks was closely associated with a clay fraction. Having investigated on analyses for Th and $U$ and leaching studies in an ancient (pre-Pennsylvanian) weathering profile, Pliler et al. (1962b) concluded that U was present largely in the primary resistates, such as zircon and apatite in the weathered rocks, but Th occurred mainly in or on clays or in the secondary resistates formed in the course of weathering.

These studies are applicable to the behavior of Th in this region; Th that had accumulated in residual soil in the source area was adsorbed on a clay mineral and then transported into the sedimentary basin. On the contrary, $U$ was adsorbed on the clay mineral in the sea water during the sedimentation possibly from the pore solution, when the clay mineral was converted into sericite.

From the results of the field and petrographical studies of the mudstone facies, it is presumed that the source area of the clayey subfacies have undergone chemical weathering for longer period than in the silty subfacies (Katada et al, 1973). This interpretation is well supported by higher $\mathrm{Th} / \mathrm{K}_{2} \mathrm{O}$ ratio in the clayey subfacies than in the silty subfacies.

Different kinds of rocks exposed in each source area seems also to reflect on the contents of Th and $U$. Granitic clasts are dominant in sandstone of the conglomerate facies but small in amount in the mudstone facies. However, $T h$ and $U$ contents, and $\mathrm{Th} / \mathrm{K}_{2} \mathrm{O}$ and $\mathrm{U} / \mathrm{K}_{2} \mathrm{O}$ ratios in the sandstone of the conglomerate facies give nearly equal values to those of the silty subfacies, in spite of the general opinion that granitic rocks contain most remarkable amounts of radioactive elements among igneous rocks. According to the authors' observations under the microscope, there are various fragments of felsic volcanic rocks as well as mafic ones in sandstones of the mudstone facies. The predominance of the materials derived from the felsic volcanic rocks may have compensated for poor granitic materials.

Organic carbon in the mudstone facies is usually less than 1 percent; the mean value of eighteen samples is 0.7 percent, ranging from 0.16 to 1.20 percent. Consequently, $U$ and $T h$ adsorbed on the carbonaceous matter are not conspicuous in amount.

The $\mathrm{U} / \mathrm{K}_{2} \mathrm{O}$ ratios of the calcareous rocks have random distribution, and almost all the ratios of them are higher than those of the clastic sediments (Fig. 3d). Ucontaining minerals besides sericite can be expected in them. In some samples one of those minerals may be fine-grained apatite because of larger amount of $\mathrm{P}_{2} \mathrm{O}_{5}$ than that in the non-calcareous rocks, as shown with affix numerals by plotted points in the figure. The $\mathrm{P}_{2} \mathrm{O}_{5}$ contents in four analyses of the calcareous rocks range from 0.38 to 2.75 percent which are much larger than 0.19 to 0.34 percent in nine non-calcarous mudstones. There is, however, no regularity between $\mathrm{P}_{2} \mathrm{O}_{5}$ and $\mathrm{U}$ contents.

Two impure limestones with high contents of 5.1 and $10.9 \mathrm{ppm}$ for $\mathrm{U}$, and $\mathbf{1 8 . 8}$ 
and 51.4 ppm for Th respectively should contain some other radioactive minerals besides apatite, but they are not yet determined.

The $T h / U$ ratio has three different trends (Fig. 3e), and the difference between the clayey and the silty subfacies can be interpreted as that in $\mathrm{Th} / \mathrm{K}_{2} \mathrm{O}$ ratio between the two. The slight difference between mudstone and sandstone of the clayey subfacies is related to the fact that the sandstone is calcareous to some extent. As discussed above, the calcarous rocks may contain some other U-containing minerals than sericite. It is naturally presumable that U-containing minerals of the same kind exist in both calcareous rocks and calcareous matrix of the sandstone.

\section{AGKNOWLEDGEMENTS}

The authors wish to express their sincere thanks to Drs. S. Ishihara, R. Ota and T. Yoshida of the Geological Survey of Japan for their helpful advice and valuable suggestions.

\section{REFERENCES}

Adams, J.A.S. and Weaver, C.E. (1958), Thoriumto-uranium ratios as indicators of sedimentary processes: example of concept of geochemical facies. Bull. Amer. Ass. Petroleum Geol., 42, 387-430.

Banno, S. and Chappell, B.W. (1969), X-ray firorescent analysis of $\mathrm{Rb}, \mathrm{Sr}, \mathrm{Y}, \mathrm{Pb}$ and $\mathrm{Th}$ in Japanese Paleozoic slates. Geoch. J., 3, 127-134.

Bloxam, T.W. (1964), Uranium, thorium, potassium and carbon in some black shales from South Wales coalfield. Geochim. Cosmochim. Acta, 28, 1177-1185.

Clarke, F.W. and Washington, N.S. (1924), The composition of the earth's crust. U.S. Geol. Surv. Prof. Pap., 127, 117 p.

Ishihara, S., Sekine, S. and Oba, K. (1969),
Uranium contents of upper Paleozoic slate and Neogene siltstone, in Natural occurrence of uranium in Japan, Part 2. Repi. Geol. Surv. Japan, 232, 221-231 (in Japanese).

- and Kanaya, H. (1973), Uranium and thorium in natural environment. Mining Geol. Spec. Issue, 5, 30-34 (in Japanese).

Kambe, N., Katada, M. and Ohmori, T. (1969), Chemical composition and sedimentary environment of the Permian Toyoma clayslates from the southern Kitakami terrain. Bull. Geol. Surv. Japan, 20, 1-11 (in Japanese).

Kanaya, H. and Katada, M. (1975), Contents of thorium, uranium and potassium, and magnetic susceptibility of the Permian Toyoma and Usuginu facies in the Southern Kitakami Mountains. Bull. Geol. Surv. Japan, 26, 13-27 (in Japanese).

Katada, M., Kambe, N. and Ohmori, E. (1973), Contents of $\mathrm{Na}_{2} \mathrm{O}$ and $\mathrm{K}_{2} \mathrm{O}$ in mudstones of the Toyoma facies of Permian age in the Southern Kitakami Mountains. Bull. Geol. Suvv. Japan, 24, 233-242 (in Japanese).

Kondo, T. (1966), Radioactivity of the black slates of the Permian Toyoma series in Miyagi Prefecture, Northeast Honshu, Japan. J. Geol. Soc. Japan, 72, 427-437 (in Japanese).

Minato, M. (1950), Toyoma-Sea, the late Permian inland-sea in the Kitakami Mountainland, NE. Honshu, Japan. Proc. Japan Acad., 26, 80-86.

Pliter, R. and Adams, J.A.S. (1962a), The distribution of thorium, uranium, and potassium in the Mancos shale. Geochim. Cosmochim. Acta, 26, 1115-1135.

- and - (1962b), The distribution of thorium and uranium in a Pennsylvanian weathering profile. Ibid., 26, 1137-1146.

Rogers, J.J.W. and Adams, J.A.S. (1969a), Thorium, in Wedepohl et al, ed., Handbook of Geochemistry, 90. Springer-Verlag, Berlin.

- and $(1969 \mathrm{~b})$, Uranium. Ibid., 92.

Shaw, D.M. (1956), Geochemistry of pelitic rocks. Part III: Major elements and general geochemistry. Geol. Soc. Amer. Bull., 67, 919-934.

Swanson, V.E. (1961), Geology and geochemistry of uranium in marine black shales - A review. U.S. Geol. Surv. Prof. Pap., 356-C, $211 \mathrm{p}$.

Working Group of the Permian-Triassic Systems (1975), Stratigraphy near the Permian-Triassic boundary in Japan and its correlation. $J$. Geol. Sac. Japan, 81, 165-184 (in Japanese). 
南部北上山地二鱼系上部の泥質岩・砂岩のトリウム・ウランおよびカリウム

$$
\text { 金谷弘・片田正人 }
$$

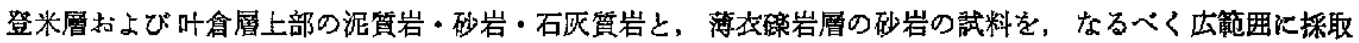
して (92 試料)，その Th，U， $\mathrm{K}_{2} \mathrm{O}$ の量を測定し，地質学的に考察した。

泥質岩・砂岩の Th，Uは普通量しか含音れていない。Uは，還元性環境下で生した“黑色直岩”中の量より はるか化少量である。したがって古登米海の海水は，Uが直接沈殿する住どは強還元性ではなかった。

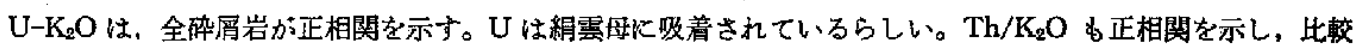
的上部の地層と下部の地層では， $\mathrm{Th} / \mathrm{K}_{2} \mathrm{O}$ 比が異なる。堆皘時の後背地の風化状態の差を示すむのかも知れな い。石灰質岩中心は，絹雲母以外にもUを含さ鉱物が存在するらしい。 